\title{
KORREKTURVERZEICHNIS
}

\section{Zukunft der Arbeit in Industrie 4.0}

Alfons Botthof und Ernst Andreas Hartmann

Am 15. März 2016 wurden in den Online- und Druckdaten der Originalversion fehlende oder unvollständige Quellenangaben für folgende Abbildungen ergänzt:

Kollaboratives Arbeiten mit Robotern - Vision und realistische Perspektive Michael Haag

DOI 10.1007/978-3-662-45915-7_6

Abb. 1 